\title{
A DESCRIPTIVE STUDY OF THE TEACHER'S TECHNIQUE ON CONTROLLING THE STUDENTS' MISBEHAVIOR IN SMPN 1 SUKASADA
}

\author{
Rini, G.A.D.P. \\ English Education Department, Ganesha University of Education \\ e-mail: dpuspitarini@gmail.com \\ Nitiasih, P.K. \\ English Education Department, Ganesha University of Education \\ e-mail: titiekjegeg@gmail.com \\ Mahayanti, N.W.S. \\ English Education Department, Ganesha University of Education \\ e-mail: surya.mahayanti@undiksha.ac.id \\ Budiarta, L.G.R. \\ English Education Department, Ganesha University of Education \\ e-mail: rahayu.budiarta@undiksha.ac.id
}

\begin{abstract}
Students in this era were already being in touch a lot by technology. This is one of the reasons why students in this era were called as digital native students. The purpose of this research was to know the impact of using digital game to improve the digital native students' English learning. Sample of this research were 25 elementary school students that chosen using lottery and they divided into 5 groups based on the digital local story game that they would play. Pre-test, post-test and interview were conducted to measure the improvement of students' English learning. The result of the pre-test and post-test showed the significance difference in the students' score. The result of the study showed that digital games can improve digital native students' English skill.
\end{abstract}

Keywords: Digital native students, digital games, English skill

\section{INTRODUCTION}

Digital native students is a learners that already being in touch with technology that born between 1995- 2012 or we can call it as Gen Z (Stillman \& Stillman, 2018). Digital native learners or Gen Z learners is an independent learners and more individualist rather than the other era. A lot of digital native students tend to study with their own way. This situation makes the teacher have to improve their way of teaching to adjust with the digital native students' need. Gamification is one of the methods that can be used for the teacher to improve students' English achievement.

Gamification can defined as a system or techniques from game-based design that can be applied in non-games context in the learning process to engage people and enhance their problem solving skill (Wood, et.al, 2013; de- Marcos, et.al, 2014; Leaning, 2015; Brull\&Finlayson, 2016; van den Boer, 2018). Sanford (2005) stated that game can support students' learning process based on the challenges that provided in the game and it can make the learners can overcome any complex problem in their live. 
According to Kiryakova, Angelova \& Yordanova (2017), they stated that gamification has major elements that need to be considered in making digital games, such as: (1) Users (the participants of the game); (2) Challenges/Tasks (the performance or obstacles in the game); (3) Points: The accumulation of the result; (4) Levels (The stages of the user depends on the point they get); (5) Badges (The rewards after completed the action or obstacles); (6) Ranking of users: The achievement of the user.

One of the media that can be used in improving students' English skill is digital game. Based on the research that conducted by Mufidah (2016), digital games can stimulated and entertained the learners a lot. Prensky (2001) stated that digital games should have 12 important elements, such as: Game were a form of fun to give enjoyment and pleasure, Game were a form of play to give intense and passionate involvement, Game has rules to give the structure, Game has goals to give motivation, Game should be interactive, Game should be adaptive, Game should provide feedback and outcomes, Game should provide win states, Game should provide challenge/competition to give adrenaline, Game should provide problem solving, Game should have interaction between user, Game also should have representation and story to give emotion Learning English through games can be the innovative way for the students to learn new things or new words that they might not hear before. The games that used for digital learning is not only deal with game that can connected via internet access, but arcade, offline games, TV or pc console also can be used as the game to improve language skill (Pekdemir, 2017).

Games are not only about how to learn language. The students also can learn their own culture in through local story game. Local story can be defined as cultural expression of a society through language that linked into different aspect in culture (Isnain, 2007). Local story usually being told or spread to maintain the culture of the society. It is important for the digital native students to know about the culture in their society especially because they need to know about their culture more.

In this research, the researcher provided some research related to digital games or gamification. Dacre, et.al (2017) conduct a gamification research that focused on how to improve engagement amongst teaching and learning stakeholders on a postgraduate course. The result of the study showed that gamification can improved the engagement and sense of partnership. Garcia \& Alvaro (2017) conduct a research in studying the impact of gamification to improve students' motivation and innovation to learn. Based on that study, gamification has strong effect to improve motivation and innovation of the students.

This research focused on how gamification media in form of digital games based on Balinese local story can be used to help digital native students or learners to improve their English.

\section{METHOD}

The design of this research was a pre experimental design using one-shot case study. The groups that used as the sample in this research were given treatment using gamification media that already developed by the researcher that based on local story. Pre-test, post-test and interview were conducted to collect the data.

The participants of this study were elementary school students in SD Lab Undiksha Singaraja. The sample of this study was 25 students that being chosen by using lottery. Those 25 students then divided into 5 groups with 5 students in each 
group. The treatment that being given was the prototype of game that already developed by the researcher.

The instrument that being used in this research were pre-test, post-test and interview guide. Pre-test and post-test were made based on the story that being used as the main story of the gamification media. There were 5 kinds of story that being used in the pre-test and post-test, such as story of Manik Angkeran, I Cupak lan I Gerantang, I Ketimun Mas, I Siap Selem and I Sugih teken I Tiwas. Pre-test and post-test consisted of 10 questions and each question had 3 answer options. The result of the pre-test and post-test were used to analyse the data. The data of pre-test and post-test would be analyse using descriptive analysis.

In the observation phase, the researcher observed the 6 grade of SD Lab Undiksha. Then, the researcher chose 1 class to be the sample for this research. The researcher did lottery to choose the participant for the research and 25 students would be chosen. Those 25 students would be divided into 5 groups, so each group had 5 students in it. Pre-test was given in the beginning before the participants learn using the game. After the pre-test was given and the participants already done learn using the game, post-test was given to them to measure their improvement after learn English using the game. After the post- test was conducted, the researcher then had interview with the participants to know how well they improve in the learning process.

\section{FINDING AND DISCUSSION}

After the participants done with their learning using digital game and done with the post-test and interview, the researcher collected the result of pre-test, post-test and interview. The data collected would be analyzed using descriptive analysis.

The result of the pre-test and post-test showed a significant difference based on the mean measurement. The result of the pre-test and post-test could be seen in Table 1 .

Table 1. Result of Pre-test and Post-test

Descriptive Statistics

\begin{tabular}{lccccc}
\hline & N & Minimum & Maximum & Mean & $\begin{array}{c}\text { Std. } \\
\text { Devi } \\
\text { ation }\end{array}$ \\
\hline Pretest & 25 & 2 & 8 & 5.6 & 1.912 \\
\hline Posttest & 25 & 4 & 10 & 8.28 & 1.429 \\
\hline $\begin{array}{l}\text { Valid N } \\
\text { (listwise) }\end{array}$ & 25 & & & & \\
\hline
\end{tabular}

Based on the table above, the minimum score of the pre-test was 2 and for the post-test the minimum score was 4 . Then the maximum score for pre-test was 8 and for post-test was 10. The mean of pre-test result was 5.6 meanwhile the mean of post-test result was 8.28. The mean result showed a significance difference between pre-test and post-test result of the students.

Based on the interview result, most of the students were enjoy to learn and play using digital game that provided by the researcher. Students also understand most of the language used in the media. The students also being motivated to learn English more after learn using digital game. The students also engage more with their friend after 
learn using digital games. The students tend to improve their way to learn using digital games and helped them to learn English in an innovative way.

Based on the table 1, the significance difference between pre-test and post-test of the study was because at the beginning, the students only being prepared with their prior knowledge to the story of the digital game. In the pre- test, the means of the test was 5.6 and for the post-test, the means was 8.28. We can see that there was a comparison of the means result of the pre-test and post-test. The standard deviation of the result also showed the value of the distribution of the data. The standard deviation of pre-test was 1.912, that meant the pre-test score that appear a lot was between $5.6-$ 1.912 and $5.6+1.912$. Meanwhile for the post-test score, the standard deviation showed the score of 1.429, it meant that the post-test score that appear a lot was between $8.28-$ 1.429 and $8.28+1.429$. The means gap between pre-test and post-test result defined that there was an improvement from the students after learn using the game.

The pre-test and post-test that being given to the students was a test with 10 questions and each question consists of 3 options. The material in the pre- test and posttest was the whole story of Balinese local story that already in form of digital games. The pre-test was provided to know how well the students know about their own local story, especially in English because not all of the school would teach about local story to students in English. Most of the students only remember a little bit of the story that being provided in the game. The students said that they only know some of the story that being provided in the game. This was the reason why the gap between pre-test and post-test result was quite far.

The students could improve their English using digital game, like what was found by Pekdemir (2017), because the digital game that being provided already had 6 basic elements of gamification and 12 important elements of game (Prensky, 2001). The game already provided with fun and enjoyable challenges that can make the learners enjoy playing the game. Each game has their own appearance to make the learners having fun and not boring. It also entertain the children at the same time (Mufidah, 2016).

The games also provided challenges that already adjusted for elementary school students' problem solving skill (Wood, et.al, 2013; de-Marcos, et.al, 2014; Leaning, 2015; Brull\&Finlayson, 2016; van den Boer, 2018). It could make the students became easier to solve any challenges in the game. The instruction also made into the language that the students would be easier to understand. The story line appeared in the game's storyboard also already adjusted to the elementary school students' language skill. This was the plus point of how the students could improve their English by using digital game the challenges and story line already being adjusted into their level of knowledge. The adjustment of level of knowledge that provided in the digital games was being the motivation (Garcia \& Alvaro, 2017) of the students to study more because they felt that the digital game was made for them to learn English easily. The students also could learn about their culture more using the digital games because the main story that used in the game was the stories that quite close with their daily life whereas the story use was local story that reflect their own culture.

The result of the test and interview of how digital games can help digital native students to learn English showed significance difference before the treatment being given and after the treatment given to the students. The digital games could improve the students' English skill by providing a new and innovative way of learning. 


\section{CONCLUSION}

As the result of this research, it showed that digital games could help the students to improve their English skill by providing a new and innovative way to learn English by themselves. The result of pre-test and post-test of the research showed significance difference between before and after the treatment were given to the students. Digital game that used to improve the students' English skill should have 6 basic gamification elements and 12 basic elements of games. Digital games also can improve motivation of the students because they can have a new environment to learn language especially in learning English. Students are not only learn about language but also their own culture that reflected in the local story that being used in the game.

\section{REFERENCES}

Brull, S., \& Finlayson, S. (2016). Importance of Gamification in Increasing Learning. 372-375.

Dacre, N., Gkogkidis , V., \& Jenkins, P. (2017). Co-Creation of Innovative Gamification Based Learning: A Case of Synchronous Partnership. SRHE International Conference on Research into Higher Education, 1-5.

de-Marcos, L., Domínguez, A., Saenz-de-Navarrete, J., \& Pagés, C. (2014). An empirical study comparing gamification and social networking on e- learning. Computers and Education, 82-91.

Garcia, L., \& Alvaro, B. (2017). Gamification in English Teaching in Primary Education.

Isnain. (2007). Cerita Rakyat. Retrieved January 10, 2019, from http://melayuonline.com/ind/culture/dig/1256/cerita-rakyat.

Kiryakova, G., Angelova, N., \& Yordanova, L. (2017). Gamification in Education.

Leaning, M. (2015). A study of the use of games and gamification to enhance student engagement, experience and achievement on a theory-based course of an undergraduate media degree. Journal of Media Practice, 155-170.

Mufidah, N. (2016). The Effect of Gamification on English Language Anxiety and Grammar Achievement.

Pekdemir, B. (2017). Digital Games in Language Learning and Teaching. Journal of Foreign Language Education and Technology, 130-142.

Stillman, D., \& Stillman, J. (2018). Generasi Z : Memahami Karakter Generasi Baru yang Akan Merubah Dunia Kerja. Jakarta: Gramedia Pustaka Utama. 